\title{
Studies on the Stabilization of Rayon Fabrics for Preparing Carbon Fabrics: 2. Fast Isothermal Stabilization Processes at High Temperature
}

\author{
Sung Bong Yoon ${ }^{1}$, Chae Wook Cho ${ }^{1}$, Donghwan Cho ${ }^{1, \wedge}$, Jong Kyoo Park ${ }^{2}$ and Jae Yeol Lee \\ ${ }^{1}$ Department of Polymer Science and Engineering, Kumoh National Institute of Technology, Gumi, Gyungbuk, 730-701 Korea \\ ${ }^{2}$ Composites Research Team, Agency for Defense Development, P.O.Box 35-4, Daejeon, Korea \\ •e-mail:dcho@kumoh.ac.kr \\ (Received September 3, 2008; Accepted December 9, 2008)
}

\begin{abstract}
In the present study, fast isothermal stabilization processes for rayon precursor fabrics were performed at $350^{\circ} \mathrm{C}$ and $400^{\circ} \mathrm{C}$ within 3 minutes and the chemical and physical characteristics of the stabilized fabrics were investigated. In addition, rayon precursor fabrics were pre-treated with three different phosphorous-based flame retardants and then stabilized. The effect of flame retardants on the chemical composition, thermal shrinkage, weight change, thermal stability and XRD results was examined, comparing with those of the precursor fabrics. The result showed that the stabilization of rayon fabrics was most effective as the stabilization temperature was $350^{\circ} \mathrm{C}$, the stabilization time was 3 min, and the pre-treatment with phosphoric acid of $1 \mathrm{vol} \%$. The carbon contents of stabilized rayon fabrics were increased with increasing stabilization temperature and time, whereas the oxygen contents were decreased. Also, it is likely that the pre-treatment with phosphoric acid plays a role in retarding the change of chemical structure of rayon fabric. The XRD result was quite consistent with the result showing the effect of phosphoric acid on the chemical composition, thermal shrinkage and weight reduction of rayon fabric.
\end{abstract}

Keywords : Rayon Fabric, Isothermal stabilization process, Flame retardant, Pre-treatment, Characterization

1. 서

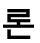

탄소섬유(carbon fiber)는 레이온(rayon), 폴리아크릴로니트 릴(polyacrylonitrile: PAN), 그리고 핏치(pitch) 세 종류의 프리 커서로부터 제조될 수 있다. 1950년대에 가장 먼저 등장하여 상업화된 제 1 세대 탄소섬유인 레이온계 탄소섬유는 다른 프리 커서로부터 제조된 탄소섬유보다 기계적 물성이 비교적 떨어 진다[1]. 그러나 레이온계 탄소섬유는 열전도도가 매우 낮아 내열 및 단열특성이 우수할 뿐만 아니라 삭마저항성을 지닌 고분자복합재료의 매트릭스로 많이 쓰이는 페놀수지와의 계면 접착성이 좋아 우주 및 국방소재용 초고온 내삭마 및 내열 복 합재료의 보강재로서 지금까지 요소요소에 사용되고 있다[2,3]. 레이온직물(rayon fabric)은 일련의 안정화공정(stabilization process)과 탄화공정(carbonization process)을 통해 화학구조가 변환되면서 탄소직물로 전환될 수 있다. 그리고 탄소직물을 구 성하고 있는 탄소섬유의 물성을 더욱 향상시키기 위하여 $2500^{\circ} \mathrm{C}$ 이상에서 장력을 주면서 흑연화공정(graphitization process)을 거치면 고강도 및 고탄성 탄소섬유가 얻어질 수 있 다[1]. 안정화공정은 PAN계 또는 핏치계 등 모든 탄소섬유에 대하여 공통적으로 행하는 열처리 단계이며, 성공적인 탄소섬 유 제조를 위해서 가장 중요한 공정이라고 해도 지나치지 않 다. 최종적으로 얻어지는 탄소섬유의 화학적, 물리적 특성은
물론 열적, 기계적 특성은 탄소섬유 프리커서(precursor) 종류, 안정화공정 조건과 방법 등 여러 가지 인자에 의존한다. 그러 므로. 안정화섬유의 화학조성, 미세구조, 물리적, 열적 그리고 기계적 거동은 탄소섬유의 특성에 매우 중요한 역할을 한다.

안정화섬유를 거쳐 탄소섬유로 전환되는 공정 과정에서 프 리커서 섬유의 화학적, 물리적 특성과 열적 특성은 크게 변한 다[4,5]. 특히 레이온 프리커서 섬유에서 이러한 특성 변화는 더욱 심각하며, 프리커서 섬유로부터 탄소섬유의 수득률은 매 우 낮다. 일반적으로 열처리온도가 높을수록 그리고 승온속도 는 낮을수록 섬유에 존재하는 탄소성분은 증가하는 반면 산소 성분은 감소한다. 일반적으로 $400^{\circ} \mathrm{C}$ 이하에서 주로 행하는 안 정화공정 중 $200^{\circ} \mathrm{C}$ 이상에서 온도가 높아짐에 따라 섬유 필 라멘트의 길이나 직경은 감소하면서 직물의 가로, 세로 및 두 께도 수축되고, 아울러 직물의 중량감소도 동반된다[6,7].

레이온섬유의 열분해는 주로 $350^{\circ} \mathrm{C} \sim 400^{\circ} \mathrm{C}$ 사이에서 발생 한다[8-10]. 레이온 프리커서의 화학구조의 변화는 상당 부분 이 온도 이하에서 진행되므로 섬유의 질량감소가 크게 발생하 고 화학구조도 달라진다. 또한, 셀룰로스는 매우 좁은 온도 범 위에서 분해가 매우 두드러지게 일어난다는 특징이 있다. 이 러한 레이온직물의 중량변화는 안정화공정이 $400^{\circ} \mathrm{C}$ 까지 온도 를 증가시키면서 진행될 때, 다음과 같이 세 영역으로 나누어 해석할 수 있다. 첫째는 질량감소가 작은 $250^{\circ} \mathrm{C}$ 이하 영역, 둘 
째는 상대적으로 질량감소와 열수축이 가장 빠르고 크게 일어 나는 $250^{\circ} \mathrm{C} \sim 350^{\circ} \mathrm{C}$ 영역, 그리고 셋째는 중량감소 속도가 완 화되는 $350^{\circ} \mathrm{C}$ 이후의 영역이다. 일반적으로 두 번째 영역에서 직물의 전체 질량의 약 $80 \%$ 이상이 손실될 수 있다. 이러한 화 학적, 물리적 변화는 공정온도와 공정시간에 따라 영향을 받는 다. 즉 낮은 안정화온도 영역에서는 화학적, 물리적 변화가 서 서히 진행되며, 높은 온도 영역에서는 상대적으로 빠르게 진행 된다. 따라서 이 온도 영역에서의 열처리공정 조건의 제어를 통 한 직물 특성의 제어는 안정화공정의 핵심이라고 할 수 있다[11]. 따라서, 본 연구에서는 레이온 프리커서 직물에 대한 안정 화공정을 회분식(batch-type) 방법으로 행하였다. 즉, $400^{\circ} \mathrm{C}$ 까 지 온도를 올려가면서 행하는 동적인 방법이 아닌, 안정화온 도를 $350^{\circ} \mathrm{C}$ 또는 $400^{\circ} \mathrm{C}$ 로 고정시키고 짧은 시간 동안 열처리 시간을 변화시키는 등온 안정화공정 방법을 사용하였다. 본 실 험에서 행한 등온 안정화공정의 주요 목적은 상대적으로 높은 $350^{\circ} \mathrm{C} \sim 400^{\circ} \mathrm{C}$ 의 안정화온도에서 3 분 이내에 레이온직물에 대 하여 안정화공정을 빠르게 진행하였을 때 발생된 여러 가지 화학적 및 물리적 특성 조사를 통하여, 고온에서 빠른 등온 안 정화공정의 적용 가능성을 타진하는 것이다. 아울러, 서로 다 른 난연제를 사용하여 전처리한 후 안정화된 레이온직물의 화 학조성, 열수축률, 중량변화, 열안정성 및 미세구조에 미치는 난연제의 영향을 조사하였으며, 그 결과를 레이온 프리커서 직 물과 비교하였다.

\section{2. 실 험}

\section{1. 재 료}

본 연구에서는 네덜란드의 Acordis사에서 제조된 레이온직 물(Acordis T-700)을 사용하여 안정화공정을 수행하였다. 안정 화공정 동안 발생한 레이온직물의 중량변화, 섬유직경 그리고 안정화 후 섬유의 열안정성에 미치는 화학전처리의 영향을 조 사하기 위하여 안정화공정을 수행하기 전에 다음과 같은 세 종류의 인계 난연제로 레이온직물의 표면을 처리하였다. 즉, 인산 (phosphoric acid, $\mathrm{H}_{3} \mathrm{PO}_{4}$, 덕산화학(주)), 3-(hydroxylphenyl phosphinyl)propanoic acid (HIRETAR-205, H-205, (주) KOLON) (Fig. 1), 그리고 FR-SH(Flame Retardant-Special Hard) (태화산업사). 첫째, 인산은 잘 알려진 난연성 유기물 중 의 하나로, 계획된 농도에 따라 수용액을 준비하여 사용하였 다. 둘째, H-205는 산업현장에서 폴리에스터 섬유가공에 사용

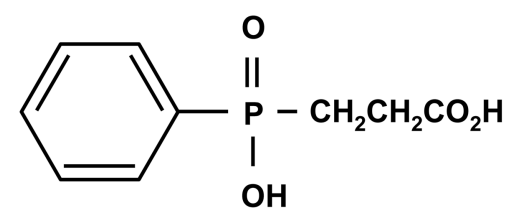

Fig. 1. Chemical structure of 3-(hydroxylphenyl phosphinyl) propanoic acid used in this work.
되는 인계 난연제로서 백색 결정성 분말이며 인을 약 $14 \%$ 이 상 함유하고 있다[12]. 수용성이며 고온에서 섬유의 변색 및 산화에 의한 물성 변화를 억제하는 효과가 있다고 알려져 있 다. 셋째, FR-SH는 자동차 내장용 의자커버용 및 산업용 폴리 에스터 직물에 사용되는 유기인산염계 난연제로서 무색 투명 한 수용성 액체이고 비교적 소량으로도 우수한 난연 성능을 나타낸다. 또한, 전처리 시 섬유의 성능 저하나 물성의 변화를 최소화하고 고온처리가 가능할 정도로 내열성이 좋은 것으로 알려져 있다. $\mathrm{pH}$ 는 $6.4 \sim 6.6$ 이며, 약한 양성을 띠는 이온성 성 질을 지니고 있다. 그러나 이에 대한 화학구조는 제공사로부 터 공개되지 않았다.

\section{2. 레이온직물의 화학전처리}

본 실험에 사용된 레이온직물의 크기는 가로 $50 \mathrm{~mm}$, 세로 $60 \mathrm{~mm}$ 로 직사각형 모양으로 절단하여 준비하였다. 준비된 직 물을 $\mathrm{H}_{3} \mathrm{PO}_{4}, \mathrm{H}-205$ 및 $\mathrm{FR}-\mathrm{SH}$ 세 종류의 난연제가 각각 $1 \mathrm{vol} \%$ 씩 수용액에 포함되어 있는 비이커에 침지하여 상온에서 60 분 동안 dip-coating 시킨 후 $80^{\circ} \mathrm{C}$ 의 오븐에서 약 6시간 이상 충 분히 건조하였다. $1 \mathrm{vol} \%$ 농도의 사용은 이전의 연구[13]에서 레이온섬유 필라멘트의 안정화에 미치는 인계 난연제 농도의 영향을 조사한 결과, $1 \mathrm{vol} \%$ 에서 가장 우수한 결과를 나타내 었기 때문이다. 난연제 처리 전과 후의 레이온직물 상태를 육 안으로 비교한 결과, 처리 전 상아색의 직물은 처리 후 연한 노랑색을 띠며 색갈이 다소 짙어지는 것으로 확인되었다. 난 연제 처리 유·무의 영향을 비교하기 위하여 화학전처리를 하 지 않은 레이온직물도 동일한 크기로 준비하여 안정화공정에 사용하였다.

\section{3. 등온 안정화공정}

레이온직물의 안정화공정은 튜브형 안정화로를 사용하여 일 정한 양의 일반등급의 공기를 $50 \mathrm{cc} / \mathrm{min}$ 의 속도로 일정하게 주 입하면서 수행하였다. 공정 시작 전 일정한 크기로 준비된 레 이온직물은 흑연판 위에 올려놓고 안정화로 내부의 가열구간 에 위치하도록 밀어 넣었다. 안정화온도를 각각 $350^{\circ} \mathrm{C}$ 와 $400^{\circ} \mathrm{C}$ 로 고정시키고 로(furnace) 내부에서 레이온직물의 노출시간을 30 초, 1 분, 2 분, 3 분씩 변화시켜가며 짧은 시간 동안 등온 안 정화공정을 진행하였다. 안정화공정은 화학전처리를 하지 않 은 레이온직물과 세 종류의 난연제를 사용하여 각각 $1 \mathrm{vol} \%$ 로 처리된 레이온직물에 대하여 각각 동일하게 수행하였다. 등온 안정화공정 전과 후에 발생한 레이온직물의 치수변화와 중량 변화를 측정하였다.

\section{4. 특성 분석}

각 안정화공정을 행하기 전과 후에 안정화로 내부에서 발생 한 레이온직물의 중량변화는 소수점 네 자리까지 측정이 가능 
한 화학분석 저울을 사용하여 조사하였다. 직물의 열수축률은 안정화공정 전과 후 직물의 가로, 세로 및 두께 변화로부터 계 산하였다.

레이온직물 프리커서, 안정화공정으로부터 얻어진 레이온직 물에 대한 화학조성을 조사하기 위하여 원소분석기(elemental analyzer, Elementar Vario EL, Elementar Analysensystem)를 사 용하였다. 시료는 $1150^{\circ} \mathrm{C}$ 정도의 고온에서 연소하여 각 시료 가 함유한 가스로 분해하여 $\mathrm{C}, \mathrm{H}, \mathrm{N}, \mathrm{S}$ 및 $\mathrm{O}$ 함량을 분석하 였다. 산소 $(\mathrm{O})$ 함량은 전체 $100 \%$ 에서 $\mathrm{C}, \mathrm{H}, \mathrm{N}, \mathrm{S}$ 각각의 함 량을 모두 더한 값을 뺀 값으로부터 결정하였다. 이 성분 이 외의 극소량의 기타 성분은 무시하였다. 또한, 인성분을 포함 하고 있는 난연제 처리 시 안정화공정 후에 직물에 잔존하고 있는 미량의 인함량은 고려하지 않았다. 이는 본 연구에서 원 소분석의 목적이 세 가지 주요 성분인 탄소, 산소, 수소 함량 의 변화 조사에 있기 때문이다.

안정화공정 전과 후 레이온직물의 열안정성에 미치는 등온 안정화시간과 난연제 처리 유·무 및 종류의 영향을 조사하기 위하여 열중량분석기(thermogravimetric analyzer, TGA 951, Du Pont)를 사용하여 $50 \mathrm{cc} / \mathrm{min}$ 의 건조 질소가스가 유입되는 불활성 분위기에서 측정하였다. 모든 $\mathrm{TGA}$ 실험은 상온부터 $800^{\circ} \mathrm{C}$ 까지 $10^{\circ} \mathrm{C} / \mathrm{min}$ 의 승온속도 조건에서 수행하였다.

레이온직물에 대하여 행한 안정화공정 조건에 따른 X-선 회 절 변화를 관찰하기 위하여 고분해능 X-선 회절분석기(highresolution X-ray diffractometer, X'Pert PRO-MNR, Philips)를 사용하였다. Scanning 범위는 $2 \theta=5^{\circ} \sim 50^{\circ}$ 이었으며 step size는 $2 \theta=0.04^{\circ}$ 였다. Step 당 소요시간은 1 초였다. 연속형 scan mode 가 적용되었으며, 사용된 radiation은 $\mathrm{K}_{\alpha}$ 이며 targeting 소재는 $\mathrm{Cu}_{\text {였다. }}$

\section{3. 결과 및 고찰}

\section{1. 수축률 및 중량감소율에 미치는 영향}

Fig. 2는 약 $50 \mathrm{~mm} \times 60 \mathrm{~mm}$ 크기의 레이온직물에 난연제 처 리를 전혀 하지 않고 공기분위기에서 각각 $350^{\circ} \mathrm{C}($ 위 $)$ 와 $400^{\circ} \mathrm{C}$ (아래)에서 각각 30 초, 1 분, 2 분 그리고 3 분 동안 안정화시켜 얻어진 직물에 대하여 안정화로 내부에서 발생한 치수변화와 중량감소의 변화를 측정한 결과이다. 각 안정화온도에서 체류 된 등온시간이 증가할수록 직물의 두께, 너비와 길이 방향에 서의 열수축률과 중량감소율이 증가하였다. 주어진 등온조건 에서 직물의 두께는 최고 $37 \%$, 너비와 길이는 각각 약 $40 \%$ 까 지 수축되었다. 안정화온도에 따른 직물의 치수변화의 차이는 크지 않았으나, $350^{\circ} \mathrm{C}$ 보다는 $400^{\circ} \mathrm{C}$ 에서 직물의 중량감소가 더 욱 큰 것으로 나타났다. 특히, 열처리시간이 3 분인 경우 $350^{\circ} \mathrm{C}$ 에서 약 $84 \%$ 그리고 $400^{\circ} \mathrm{C}$ 에서는 약 $96 \%$ 의 심각한 중량감소 가 발생하였다. 따라서, 안정화공정 후에 로 내부에 남아있는 직물의 잔여중량을 고려할 때, $400^{\circ} \mathrm{C}$ 에서 3 분 처리는 $95 \%$ 이
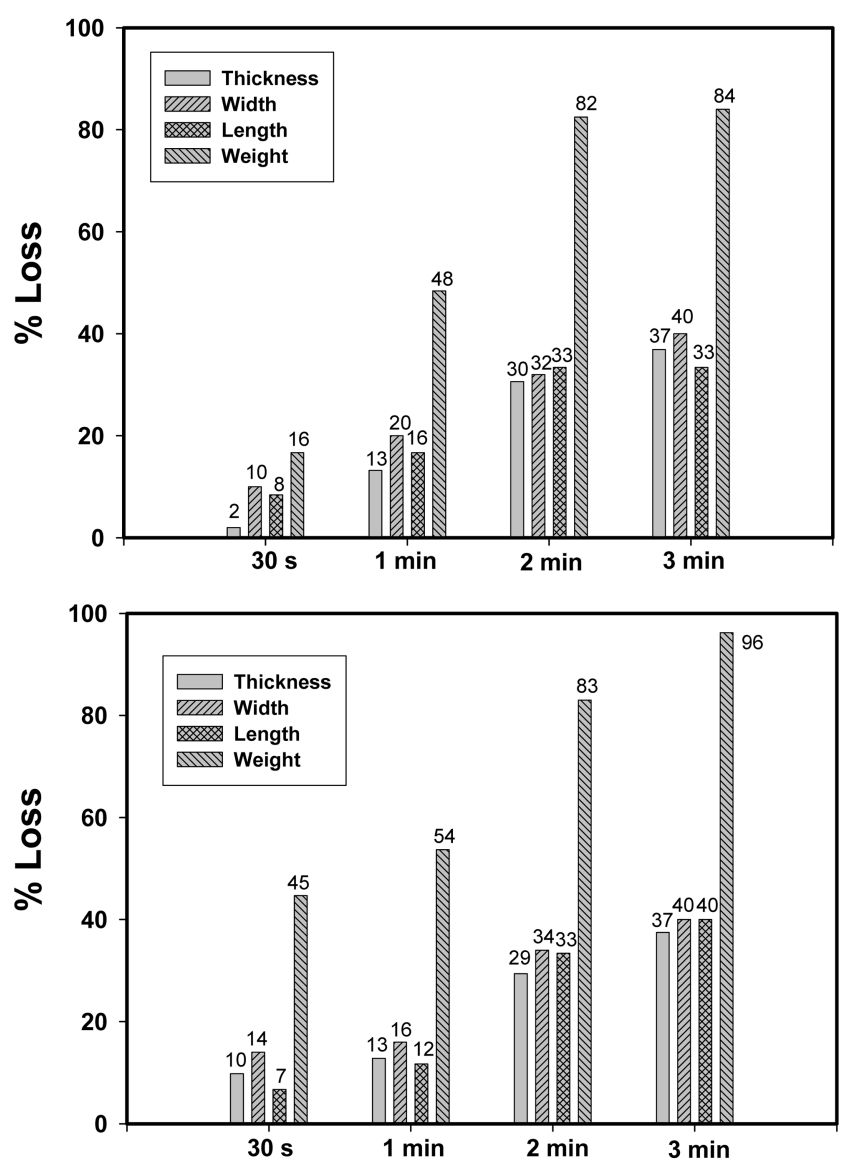

Fig. 2. Thermal shrinkage and weight loss of the untreated rayon fabrics after stabilization process at $350^{\circ} \mathrm{C}$ (top) and $400^{\circ} \mathrm{C}$ (bottom) for different durations in air.

상의 중량감소 때문에 바람직하지 않다고 판단되었다. 그리고 두 온도 모두에서 1 분 이하의 안정화시간에서 얻어진 약 $48 \%$ $54 \%$ 의 중량감소 결과를 볼 때, 레이온 프리커서의 특징인 안 정화공정 중에 발생하는 열수축이나 중량감소가 충분히 진행 되지 않았으므로, 이 조건에서는 직물의 안정화가 충분히 이 루어지지 않았다고 판단되었다.

Fig. 3의 위 그래프는 세 종류의 인계 난연제로 각각 $1 \mathrm{vol} \%$ 씩 레이온직물을 전처리한 후 공기분위기 하의 $350^{\circ} \mathrm{C}$ 에서 3 분 동안 등온 안정화공정을 행한 후, 직물의 수축률과 중량감 소율을 측정한 결과이다. Fig. 2 에서 안정화온도 $350^{\circ} \mathrm{C}, 3$ 분에 해당하는 결과와 비교할 때, 난연제로 처리하여 얻은 안정화 직물의 열수축에 의한 너비방향에서의 감소는 최고 약 $38 \%$ 까 지, 그리고 길이방향에서의 감소는 최고 $27 \%$ 까지 줄어들었음 을 확인할 수 있었다. 또한, 직물의 중량감소는 인산의 경우 $80 \%$ 로부터 $63 \%$ 로 $17 \%$ 가 낮아졌다. 이러한 이유는 화학전처 리된 레이온직물을 구성하고 있는 각 섬유의 직경이 처리하지 않은 경우와 비교할 때, 안정화공정 후에도 크게 감소되지 않 았기 때문인 것으로 설명할 수 있다. 결과는 세 난연제 중에 서 열수축과 중량감소 억제에는 인산이 상대적으로 효과가 더 
크다는 것을 제시하고 있다.

Fig. 3 의 아래 그래프는 $400^{\circ} \mathrm{C}$ 에서 3 분 동안 등온 안정화공 정을 마친 직물에 대한 결과이다. 직물의 치수변화와 중량감 소 경향은 $350^{\circ} \mathrm{C}$ 에서와 유사하였으나, 그 감소 정도는 차이가 있었다. 특히, 인산의 경우 직물 길이방향과 너비방향에서 수 축률은 상대적으로 낮은 것으로 조사되었다. 이는 $400^{\circ} \mathrm{C}$ 에서 도 인산의 난연 효과가 있다는 것을 보여준다. $400^{\circ} \mathrm{C}$ 에서는 세 종류의 난연제 중 인산이 직물의 수축이나 중량감소 억제 에 가장 큰 효과가 있는 것으로 판단되었다. 이러한 결과는 Fig. 2 에서 $400^{\circ} \mathrm{C}, 3$ 분 동안 등온 안정화로부터 얻은 결과로부 터 제시된 바와 같이, 약 $96 \%$ 에 이르는 심각한 중량감소 현 상이 인산의 처리에 의해 크게 저하될 수 있음을 의미한다.

\section{2. 열안정성에 미치는 영향}

Fig. 4 는 공기분위기의 $350^{\circ} \mathrm{C}($ 위 $)$ 와 $400^{\circ} \mathrm{C}($ 아래 $)$ 에서 각각
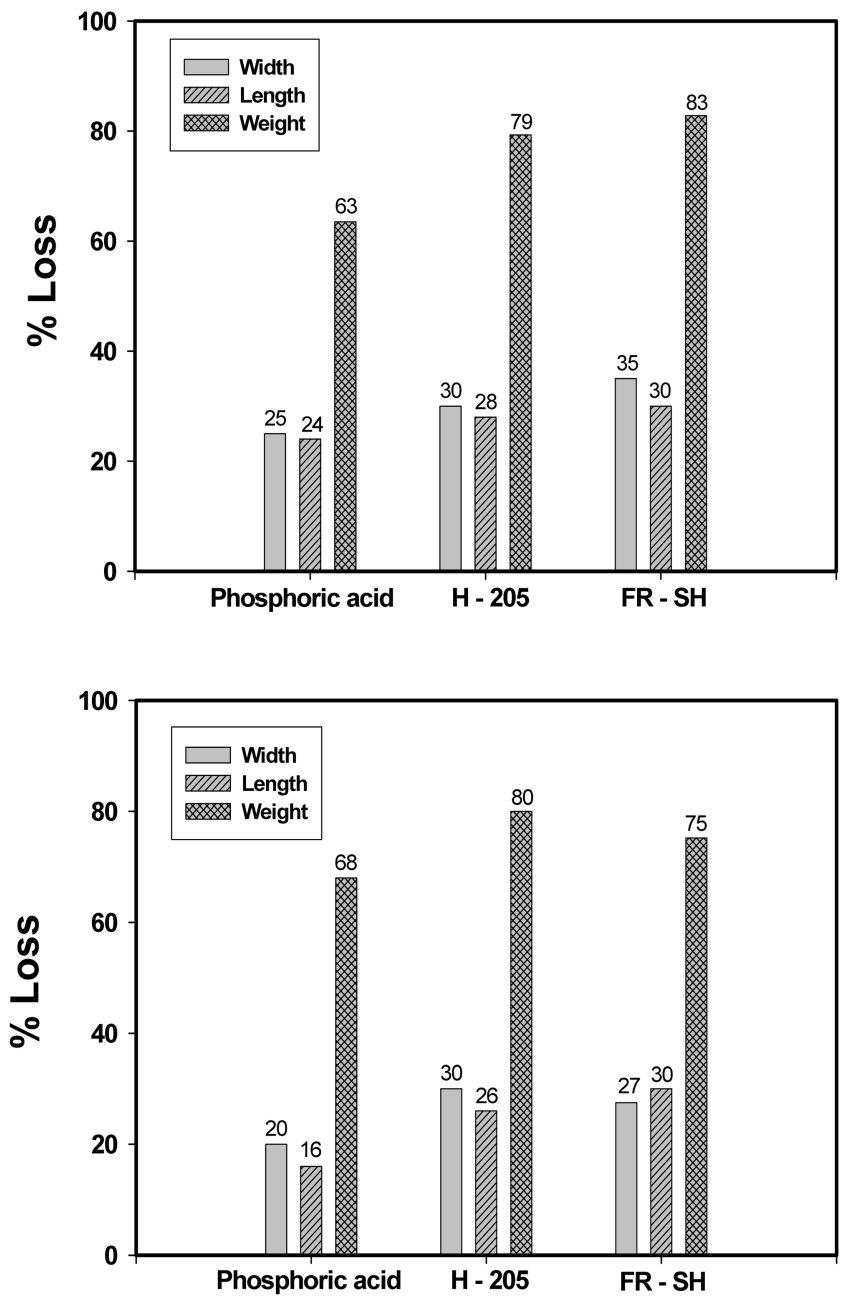

Fig. 3. Thermal shrinkage and weight losses of the rayon fabrics surface-treated with different flame retardants of $1 \mathrm{vol} \%$ after stabilization process at $350^{\circ} \mathrm{C}$ (top) and at $400^{\circ} \mathrm{C}$ (bottom) for $3 \mathrm{~min}$ in air.
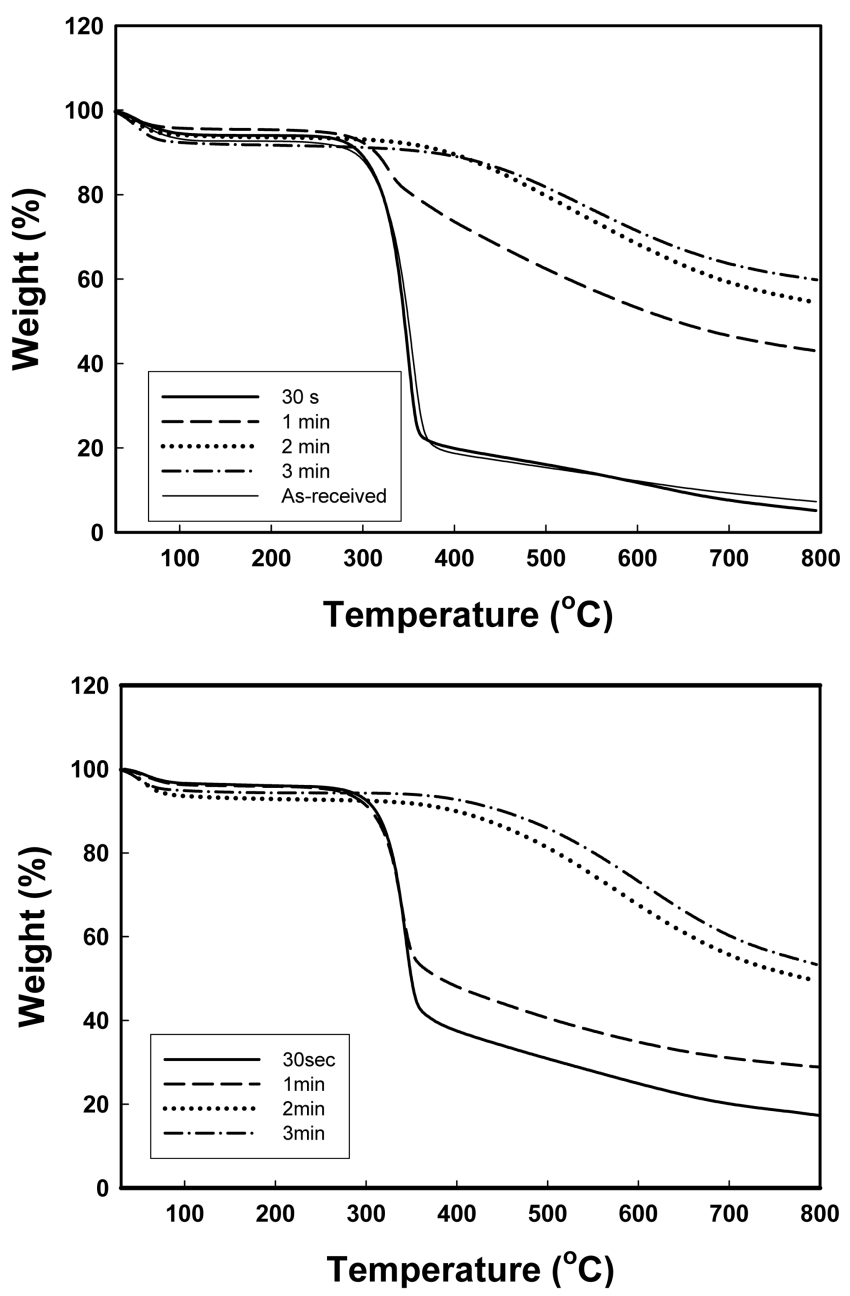

Fig. 4. TGA thermograms of the untreated rayon fabrics stabilized at $350^{\circ} \mathrm{C}$ (top) and $400^{\circ} \mathrm{C}$ (bottom) for different durations in air, respectively. TGA measurements were conducted in purging $\mathrm{N}_{2}$ atmosphere.

30 초, 1 분, 2 분 및 3 분 동안 등온 안정화공정을 경험한 난연제 로 전처리를 하지 않은 레이온직물에 대한 열안정성을 보여주 는 TGA 결과이다. 열분석은 $10^{\circ} \mathrm{C} / \mathrm{min}$ 의 승온속도로 불활성 분위기에서 $800^{\circ} \mathrm{C}$ 까지 수행하였다. 30 초 동안 안정화공정을 거친 레이온직물은 ‘as-received' 프리커서 레이온직물과 유사 한 중량감소 거동을 보여주었다. 즉, 이 온도와 시간에서 레이 온직물은 전혀 안정화되지 않았음을 의미하며, 직물의 색상도 거의 그대로 유지되면서 초기 열처리 전의 직물 상태와 유사 함을 확인할 수 있었다. 프리커서로부터 안정화가 진행됨에 따 라 레이온직물의 색상이 상아색 $\rightarrow$ 노란색 $\rightarrow$ 갈색 $\rightarrow$ 진갈 색 $\rightarrow$ 검정색으로 점차적으로 변화되었다. $350^{\circ} \mathrm{C}$ 와 $400^{\circ} \mathrm{C}$ 모 두에서 안정화시간이 3 분까지 증가됨에 따라 안정화직물의 열 안정성은 더욱 향상되었다.

$\mathrm{TGA}$ 결과는 $350^{\circ} \mathrm{C}$ 와 $400^{\circ} \mathrm{C}$ 사이에서 등온 안정화시간 2 분 이 경과하기 전에 레이온섬유의 화학적 및 물리적 변화를 동 


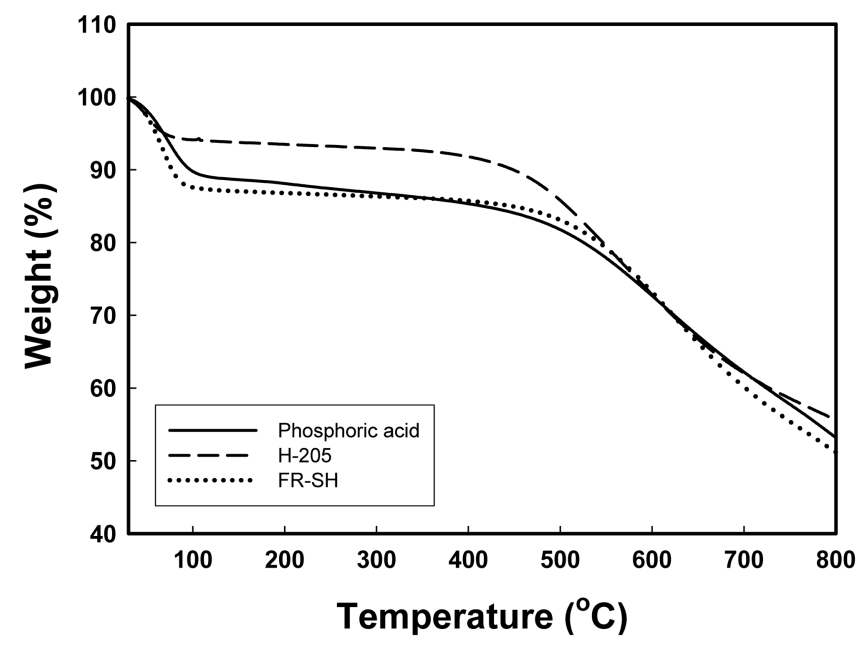

Fig. 5. TGA thermograms of the rayon fabrics surface-treated with different flame retardants of $1 \mathrm{vol} \%$ and then stabilized at $350^{\circ} \mathrm{C}$ for $3 \mathrm{~min}$ in air.

반한 안정화 반응이 가장 두드러지게 일어났음을 나타내고 있 다. 즉, 열처리공정을 마친 레이온직물이라도 2 분보다 짧은 시 간에 안정화를 경험한 직물에 포함되어 있는 휘발성분의 제거 가 가장 활발하게 발생하였음을 의미한다. 그러므로 2 분보다 짧은 열처리시간은 레이온직물의 안정화에 충분하지 않다고 판단되었다. 안정화시간이 2 분 이상일 때, $400^{\circ} \mathrm{C}$ 이후의 영역 에서 열안정성은 크게 향상되었다. 이러한 결과는 $350^{\circ} \mathrm{C}$ 와 $400^{\circ} \mathrm{C}$ 에서 2 분과 3 분 동안의 열처리가 레이온직물의 안정화 에 크게 영향을 준다는 것을 간접적으로 제시하여 주는 것이
다. 각 시편의 $\mathrm{TGA}$ 결과로부터 열처리시간이 상대적으로 긴 안정화직물에 대한 $300^{\circ} \mathrm{C}$ 이전에서의 열안정성은 열처리시간 이 짧은 것의 열안정성보다 다소 낮았다. 그 이유는 체류시간 이 길어짐에 따라 안정화공정 중 섬유표면에 산소를 포함하고 있는 유기관능기가 더 많이 형성되며, 이들은 주어진 열분석 조건에서 섬유표면으로부터 이탈되었기 때문이다. TGA 측정 에 사용된 모든 시료에서 약 $350^{\circ} \mathrm{C}$ 이후에 발생하는 2 차 중량 감소는 안정화된 레이온직물의 후속 열분해와 초기 탄화에 의 한 것이라 해석된다.

Fig. 5는 세 종류의 난연제를 $1 \mathrm{vol} \%$ 농도로 프리커서 레이 온직물에 전처리한 후 공기분위기에서 $350^{\circ} \mathrm{C}$ 에서 3 분 동안 등 온 안정화공정을 경험한 직물에 대하여 조사한 TGA 결과이 다. Fig. 4에서 보여준 결과와 유사하게, $100^{\circ} \mathrm{C}$ 이전에서 약 $10 \% \sim 12 \%$ 의 중량감소와 약 $400^{\circ} \mathrm{C}$ 이후에서 2 차 중량감소가 관찰되었다. $400^{\circ} \mathrm{C}$ 이후의 중량감소는 레이온직물이 안정화공 정 시 노출된 온도 이상에서 열분해가 진행되고 탄화 현상이 시작되기 때문이다. H-205로 전처리되고 안정화된 레이온직물 의 $500^{\circ} \mathrm{C}$ 이전에서 열안정성이 가장 높은 것으로 관찰되었다. 세 종류의 난연제 중에서는 인산으로 처리하고 안정화된 직물 의 열안정성이 상대적으로 낮은 것으로 조사되었으나, Fig. 2 와 3에서 보여주었듯이, 안정화공정을 수행하고 레이온직물에 난연성을 부여하는 데 효과가 있는 것으로 판단되었다.

결론적으로 난연제 처리를 하지 않고 안정화된 직물보다는 처리한 것이, $350^{\circ} \mathrm{C}$ 보다는 $400^{\circ} \mathrm{C}$ 에서 안정화시킨 것이, 그리 고 3분 이내에서 열처리시간이 길수록 안정화직물은 더 높은 열안정성을 나타내었다.

Table 1. A Comparison of the Chemical Compositions Measured for the Rayon Fabrics after Isothermal Stabilization Processes at Different Stabilization Temperature and Time and with Different Flame Retardants

\begin{tabular}{|c|c|c|c|c|c|}
\hline Sample & $\mathrm{C}$ & $\mathrm{H}$ & $\mathrm{O}$ & $\mathrm{N}$ & $\mathrm{S}$ \\
\hline Precursor Rayon Fabric & 38.85 & 6.39 & 54.18 & 0.25 & 0.33 \\
\hline No Treatment $\left(350^{\circ} \mathrm{C}\right), 30 \mathrm{~s}$ & 42.69 & 5.59 & 51.11 & 0.25 & 0.36 \\
\hline No Treatment $\left(350^{\circ} \mathrm{C}\right), 1 \mathrm{~min}$ & 49.50 & 5.88 & 44.24 & 0.12 & 0.26 \\
\hline No Treatment $\left(350^{\circ} \mathrm{C}\right), 2 \mathrm{~min}$ & 69.56 & 4.36 & 25.72 & 0.15 & 0.21 \\
\hline No Treatment $\left(350^{\circ} \mathrm{C}\right), 3 \mathrm{~min}$ & 73.28 & 3.64 & 22.65 & 0.16 & 0.27 \\
\hline No Treatment $\left(400^{\circ} \mathrm{C}\right), 30 \mathrm{~s}$ & 46.92 & 6.39 & 46.29 & 0.11 & 0.29 \\
\hline No Treatment $\left(400^{\circ} \mathrm{C}\right), 1 \mathrm{~min}$ & 49.40 & 6.20 & 43.68 & 0.18 & 0.54 \\
\hline No Treatment $\left(400^{\circ} \mathrm{C}\right), 2 \mathrm{~min}$ & 74.12 & 4.41 & 20.91 & 0.14 & 0.42 \\
\hline No Treatment $\left(400^{\circ} \mathrm{C}\right), 3 \mathrm{~min}$ & 78.19 & 3.99 & 17.27 & 0.22 & 0.33 \\
\hline $\mathrm{H}_{3} \mathrm{PO}_{4} 1 \mathrm{vol} \%, 350^{\circ} \mathrm{C}, 3 \mathrm{~min}$, in air & 62.69 & 3.60 & 33.38 & 0.09 & 0.24 \\
\hline $\mathrm{H}-2051 \mathrm{vol} \%, 350^{\circ} \mathrm{C}, 3 \mathrm{~min}$, in air & 74.38 & 3.28 & 21.76 & 0.09 & 0.49 \\
\hline FR-SH 1 vol $\%, 350^{\circ} \mathrm{C}, 3 \mathrm{~min}$, in air & 73.85 & 3.15 & 21.86 & 0.61 & 0.53 \\
\hline $\mathrm{H}_{3} \mathrm{PO}_{4} 1 \mathrm{vol} \%, 400^{\circ} \mathrm{C}, 3 \mathrm{~min}$, in air & 60.57 & 3.46 & 35.48 & 0.14 & 0.35 \\
\hline $\mathrm{H}-2051 \mathrm{vol} \%, 400^{\circ} \mathrm{C}, 3 \mathrm{~min}$, in air & 72.40 & 3.38 & 23.95 & 0.11 & 0.16 \\
\hline FR-SH $1 \mathrm{vol} \%, 400^{\circ} \mathrm{C}, 3 \mathrm{~min}$, in air & 68.46 & 2.75 & 26.21 & 2.37 & 0.21 \\
\hline
\end{tabular}




\section{3. 화학조성에 미치는 영향}

Table 1은 프리커서 레이온직물과 여러 가지 안정화공정을 통해 얻어진 레이온직물에 대하여 원소분석기를 사용하여 조 사한 화학조성 결과를 보여준다. 이 결과는 안정화공정 시 적 용한 난연제 처리의 유·무, 난연제의 종류, 안정화온도 및 안 정화시간이 섬유의 화학조성에 미치는 영향을 보여준다. 먼저, 프리커서 레이온직물의 화학조성은 평균적으로 산소 $54 \%$, 탄 소 $39 \%$, 수소 $6.4 \%$, 질소 $0.3 \%$ 그리고 황 $0.3 \%$ 인 것으로 조 사되었다. 안정화공정을 거친 후 레이온직물에 포함되어 있는 산소함량은 감소되는 반면, 탄소함량은 크게 증가하였다. 또한 안정화온도가 높고 처리시간이 길수록 안정화된 레이온직물의 탄소함량은 더욱 증가한 반면, 산소함량은 더욱 감소하였다. $350^{\circ} \mathrm{C}$ 와 $400^{\circ} \mathrm{C}$ 에서 30 초와 1 분 동안 열처리한 경우를 제외하 고는, 다른 공정으로부터 얻은 안정화직물의 탄소함량은 공정 조건에 따라 약 $60 \% \sim 78 \%$ 그리고 산소함량은 약 $17 \% \sim 35 \%$ 범위를 나타내었다.

안정화공정에 따른 각각의 영향을 살펴보면, 난연제 처리를 하지 않은 안정화직물의 탄소함량이 처리를 한 경우보다 다소 높은 것으로 조사되었다. 또한, 열처리시간이 길어질수록 안정 화직물의 탄소함량은 증가하고 산소함량은 감소하였다. 동일 한 안정화공정을 거친 후 난연제 종류의 영향을 보면, H-205 로 처리한 레이온직물의 탄소함량이 상대적으로 높고, 인산으 로 처리한 것이 가장 낮은 탄소함량과 가장 높은 산소함량을 나타내었다. 또한, 동일한 난연제를 사용하고 3 분 동안 안정화 시킨 레이온직물은 온도가 $350^{\circ} \mathrm{C}$ 인 경우가 $400^{\circ} \mathrm{C}$ 인 경우보다 다소 높은 탄소함량과 낮은 산소함량을 나타내었다.

원소분석으로부터 얻어진 화학조성 결과만을 고려한다면, 공기 중에서 안정화공정을 거친 레이온직물에 포함되어 있는 산소함량을 줄이고 동시에 탄소함량을 증가시키기 위해서는 난연제로 전처리를 하지 않고 $400^{\circ} \mathrm{C}$ 에서 열처리하는 것이 바 람직한 것으로 판단되었다. 레이온직물을 인계 난연제로 처리 한 경우 탄소함량이 상대적으로 낮게 나타난 이유는 난연제가 안정화공정을 촉진시켜 화학적으로 산소나 수소 등의 원소들 이 열분해에 의하여 제거되면서 탄소성분으로 전환되는 시간 을 단축하여 안정화에 이르는 시간을 줄여주었기 때문인 것으 로 사료된다.

\section{4. 미세구조에 미치는 영향}

Fig. 6은 프리커서 레이온직물에 대한 XRD 분석 결과이다. 약 $2 \theta=22^{\circ}$ 에 보이는 강한 피크는 셀룰로스의 monoclinic unit cell의 (002)면으로부터 기인된 것이다. 약 $2 \theta=16.5^{\circ}$ 부근의 작 은 피크는 monoclinic unit cell의 (101)면을 가리킨다. 그리고 최대 피크 $2 \theta=22^{\circ}$ 가까이에 위치하고 있는 약 $2 \theta=20^{\circ}$ 부근 의 피크는 unit cell의 (101)면에 해당되는 것으로 프리커서 레 이온직물을 구성하고 있는 섬유가 셀룰로스 II 결정구조를 이 루고 있다는 것을 나타낸다[14,15].

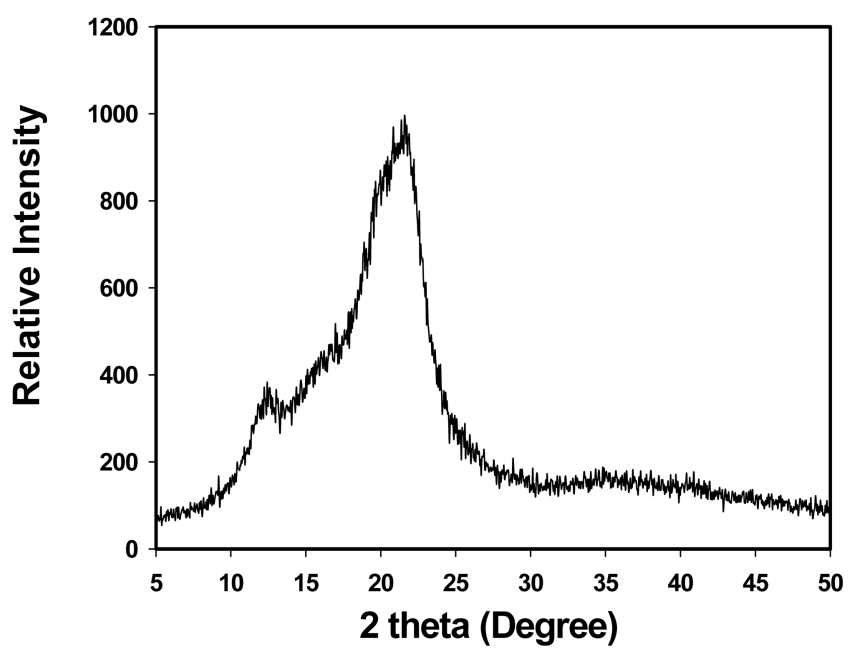

Fig. 6. XRD diffractogram of precursor rayon fabric.

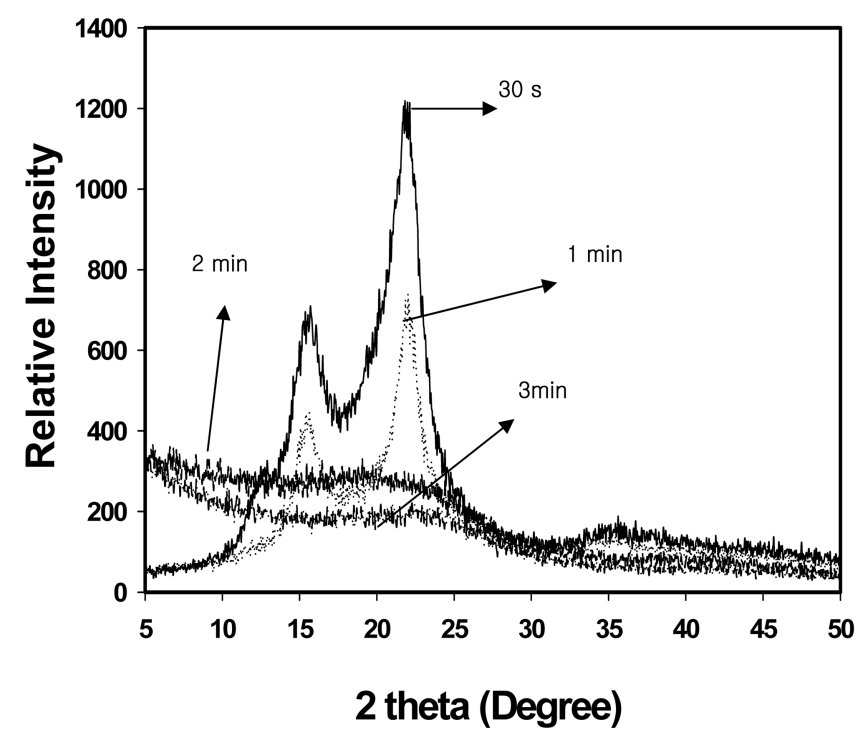

Fig. 7. XRD diffractograms of untreated rayon fabrics stabilized at $350^{\circ} \mathrm{C}$ for different durations in air.

Fig. 7 은 $350^{\circ} \mathrm{C}$ 에서 30 초에서 3 분까지 안정화시간을 변화시 키면서 공정을 행한 후 얻은 레이온직물에 대한 XRD 결과를 보여준다. 직물에 난연제 처리는 하지 않았다. 안정화공정 시 간이 길어질수록 $2 \theta=16.5^{\circ}$ 와 $22^{\circ}$ 에서의 특성 피크 높이가 현 저하게 줄어들었음을 확인할 수 있다. 2 분 이상 등온 안정화 시 두 피크는 거의 사라졌다. XRD 피크세기가 감소하거나 폭 이 넓어지는 현상은 결정크기의 감소를 의미하며, 이는 셀룰로 스 구조에서 질서도가 줄어들거나 상실되었기 때문이다. 즉, 상 대적으로 긴 안정화시간에서 레이온 프리커서섬유가 지니고 있는 전형적인 결정구조가 안정화공정에 의해서 파괴되기 시 작하면서 셀룰로스의 6각의 고리구조로부터 방향족 구조가 서 서히 형성되기 시작하면서 안정화 구조를 취하게 됨을 가리킨 


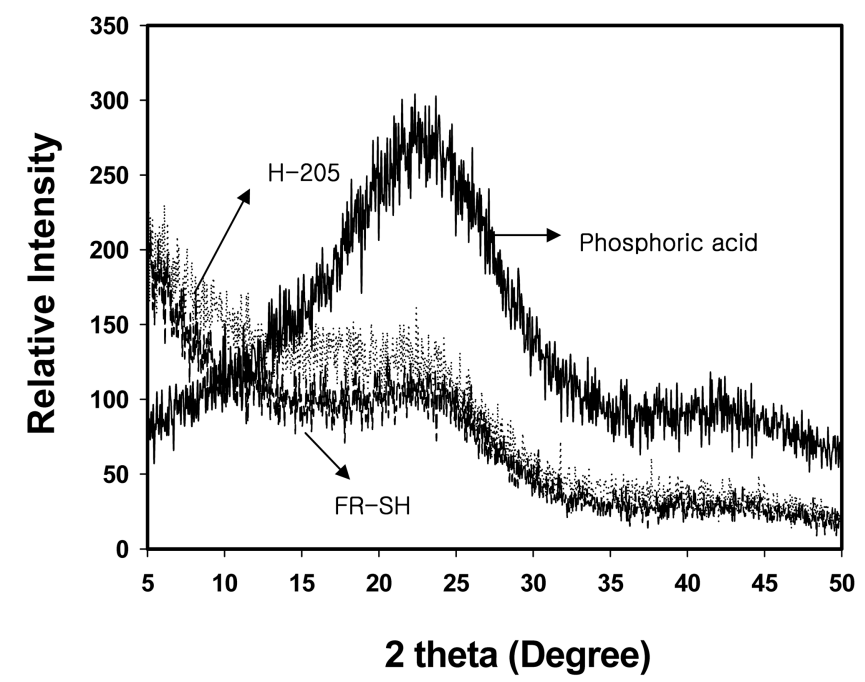

Fig. 8. XRD diffractograms of rayon fabrics surface-treated with different flame retardants of $1 \mathrm{vol} \%$ and then stabilized at $350^{\circ} \mathrm{C}$ for $3 \mathrm{~min}$ in air.

다. 30 초와 1 분의 짧은 공정시간의 경우 $2 \theta=16.5^{\circ}$ 와 $22^{\circ}$ 에서 피크의 세기와 뽀족함이 더욱 뚜렷하게 나타났다. 이 피크는 프리커서 직물을 이루고 있는 레이온섬유들이 이 온도와 시간 조건에서 셀룰로스의 전형적인 결정구조를 그대로 유지하고 있음을 나타낸다. 또한, $2 \theta=16.5^{\circ}$ 와 $22^{\circ}$ 에서 피크세기의 증가 와 함께 피크 폭이 좁아지면서 뾰족해지는 현상은 안정화가 충분히 진행되기 전 초기 열처리과정에서 레이온섬유의 결정 화도 및 결정크기는 증가하였다 것을 의미하고 있다. 안정화 공정 초기 단계에서 오히려 셀룰로스의 결정구조가 발달되는 것으로 판단된다.

Fig. 8은 인산, H-205, FR-SH 세 종류의 난연제로 각각 $1 \mathrm{vol} \%$ 농도에서 전처리하여 $350^{\circ} \mathrm{C}$ 에서 3 분 동안 공기중에서 안정화공정을 거친 레이온직물의 XRD 결과를 보여준다. 앞에 서 언급한 바와 같이, $2 \theta=16.5^{\circ}$ 에서 보여주었던 피크는 완전 히 사라졌으며, $2 \theta=22^{\circ}$ 의 피크는 전체적으로 세기가 크게 줄 어들었다. 인산의 경우에는 $2 \theta=22^{\circ}$ 의 피크가 H-205와 FR-SH 에 비해 상대적으로 크게 나타났다. 이는 인산으로 레이온직 물을 처리하는 것이 레이온의 결정구조를 더 오래 유지하는데 기여한 것으로 판단된다. 이러한 현상은 인산처리가 안정화공 정 시 레이온직물의 화학구조 변환을 좀 더 지연시키는 역할 을 하였음을 보여주는 것이다. 이와 같은 XRD 결과는 앞에서 언급된 화학조성과 열수축률, 중량감소 변화 등에 미치는 인 산의 영향에 대한 결과와도 일치한다.

\section{4. 결 론}

세 종류의 인계 난연제인 인산, H-205 및 FR-SH로 각각 전 처리된 레이온직물에 대하여 공기 중에서 수행한 등온 안정화
공정 과정에서 열처리로 내부에서 발생한 직물의 열수축률과 중량감소율을 조사한 결과, 안정화온도는 $350^{\circ} \mathrm{C}$, 안정화시간 은 3 분 그리고 $1 \mathrm{vol} \%$ 농도의 인산처리가 레이온직물의 안정 화에 가장 효과가 있었음을 확인하였다. 전처리를 전혀 하지 않은 상태에서 직물을 안정화한 것보다는 난연제로 전처리한 것이, $350^{\circ} \mathrm{C}$ 보다는 $400^{\circ} \mathrm{C}$ 에서 안정화시킨 것이, 그리고 안정 화시간이 길수록 안정화직물은 더 높은 열안정성을 나타내었 다.

안정화공정을 거친 후 레이온직물에 포함되어 있는 탄소함 량은 안정화온도가 $350^{\circ} \mathrm{C}$ 인 경우 최고 약 $73 \%, 400^{\circ} \mathrm{C}$ 인 경우 약 $78 \%$ 까지 증가하였으며, 난연제로 전처리한 경우에는 안정 화반응이 지연되면서 탄소함량이 약 $61 \% \sim 63 \%$ 까지 저하되었 다. 또한 안정화온도가 높고 처리시간이 길수록 안정화된 레 이온직물의 탄소함량은 더욱 증가한 반면, 산소함량은 더욱 감 소하였다. 안정화공정을 거친 레이온직물에 포함되어 있는 산 소함량을 줄이고 동시에 탄소함량을 증가시키기 위해서는 난 연제로 전처리를 하지 않고 $400^{\circ} \mathrm{C}$ 에서 열처리하는 것이 적절 한 것으로 조사되었다.

레이온직물의 안정화가 충분히 진행되지 않은 공정 초기단 계에서 프리커서 섬유를 이루고 있는 셀룰로스 결정구조는 다 소 발달되는 것으로 사료되었다. 그러나 안정화공정 시간이 길 어질수록 $2 \theta=16.5^{\circ}$ 와 $22^{\circ}$ 에서의 특성피크 높이가 현저하게 줄 어들었다. $350^{\circ} \mathrm{C}$ 에서 2 분 이상 등온 안정화공정 시 두 특성피 크는 거의 사라졌다. 인산처리가 안정화공정 시 레이온직물의 화학구조 변환을 좀 더 지연시키는 역할을 하는 것으로 판단 되었다.

\section{감사의 글}

본 연구는 국방과학연구소의 연구비지원에 의해 수행되었으 므로 이에 감사드립니다.

\section{참고문헌}

[1] Bahl, O. P.; Shen, Z.; Lavin, J. G; Ross, R. A. in "Carbon Fibers" $3^{\text {rd }}$ Ed. (Donnet, J.-B.; Wang, T. K.; Peng, J. C. M. Editors.), Marcel Dekker, New York, 1998, Chapter 1.

[2] Bacon, R. in "Chemistry and Physics of Carbon", Vol. 9 (Walker, Jr., P. L.; Thrower, P. A. Eds.), Marcel Dekker, New York, 1973, 1.

[3] Peebles, L. H. in "Carbon Fibers: Formation, Structure, and Properties", CRC Press, 1995, Chapter 2.

[4] Tang, M. M.; Bacon, R. Carbon 1964, 2, 211.

[5] Bacon, R.; Tang, M. M. Carbon 1964, 2, 221.

[6] Broido, A.; Nelson, M. A. Combustion and Flame 1975, 24, 263.

[7] Jones, B. F.; Duncan, R. G. J. Mater. Sci. 1971, 6, 289. 
[8] Lipska, A. E.; Wodley, F. A. J. Appl. Polym. Sci. 1969, 13, 851.

[9] Duffy, J. V. J. App. Polym. Sci. 1971, 15, 715.

[10] Shafizadeh, F.; Bradbury, A. G. W. J. Appl. Polym. Sci. 1979, 23, 1431.

[11] Cho, D.; Lee, J.; Park, J. K. J. Soc. Adhesion Interface, Korea 2004, 5(3), 10 .
[12] www.kolonls.co.kr

[13] Yoon, S. B.; Cho, D.; Park, J. K. Polymer(Korea) 2005, 29(2), 211.

[14] Basch, A.; Lewin, M. J. Polym. Sci.: Polym. Chem. Ed. 1973, 11, 3071.

[15] Kumar, K.; Saxena, R. K.; Kothari, R.; Suri, D. K.; Kaushik, N. K.; Bohra, J. N. Carbon 1998, 36, 1842. 